ロクロニウムの上手な使い方

\title{
ロクロニウムの一般的臨床使用の実際 一帝王切開術一
}

奥富俊之*

\begin{abstract}
[要旨]一般的には用量を適切に選択すればロクロニウムはスキサメトニウム同様作 用発現が速く，蓄積性が少ないが，帝王切開術の際に用いるためには，妊娠という生 理的変化, 子宮胎盤血流を介しての胎児の存在, 短時間手術, 全身麻酔が適応となっ た病態をふまえて使用する必要がある. それらの特殊性ゆえ現段階で, 両筋弛緩薬の 優劣はつけ難い．すなわちロクロニウムはスキサメトニウムにみられる副作用の軽減 には有用だが, 帝王切開においては作用発現時間, 持続時間の面で完全ではない.し たがって帝王切開術に対する全身麻酔の適応と筋弛緩薬の選択には慎重な考慮が必要 であり，一般手術より帝王切開術で遭遇頻度の高い挿管困難に対する対策を万全に整 えておくべきである.

キーワード : 妊娠, 生理的変化, 経胎盤的薬物移行, 挿管困難
\end{abstract}

（日臨麻会誌Vol.28 No.4, $678 ＼mathrm{~ 684, ~ 2008 ） ~}$

\section{はじめに}

用量を適切に選択すればスキサメトニウム同様の 速い作用発現が得られ，蓄積性の少ない中時間作用 性のロクロニウムはベクロニウムに代わる非脱分極 性筋弛緩薬として日本で普及してきているが，個々 の手術に対する有用性については検討の余地がある。 帝王切開に対する適応もその一つであり，必ずしも その利点があるかどうかは現時点では明らかではな い.それは，(1)妊婦という生理的に特殊な状況であ ること，(2)子宮胎盤血流を介して未熟な個体が存在 すること, (3)手術自体 30 分から 1 時間程度で終了す るものであること, (4)筋弛緩を必要とする全身麻酔
の適応がきわめて緊急性の高い状況，または妊婦が 区域麻酔の禁忌となるような病態にあることなどが その原因である。本稿ではそれらを中心に考察する。

\section{I＼cjkstart筋弛緩薬が胎児に及ぼす影響}

Abouleish らは，4〜 6mg/kgのチオペンタールと $0.6 \mathrm{mg} / \mathrm{kg}$ のロクロニウムで帝王切開術の麻酔導入 を行ってもApgar スコアや新生児神経行動学的評価 尺度に不利益な影響は及ぼさないと報告した ${ }^{1)}$ 。た だし，この研究は合併症をもたない正期妊産婦を対 象とした少数例の検討であり，これだけで胎児に対 する安全性を確定することはできない.

Fortier らは新生児, 成人相当のラットの横隔神 


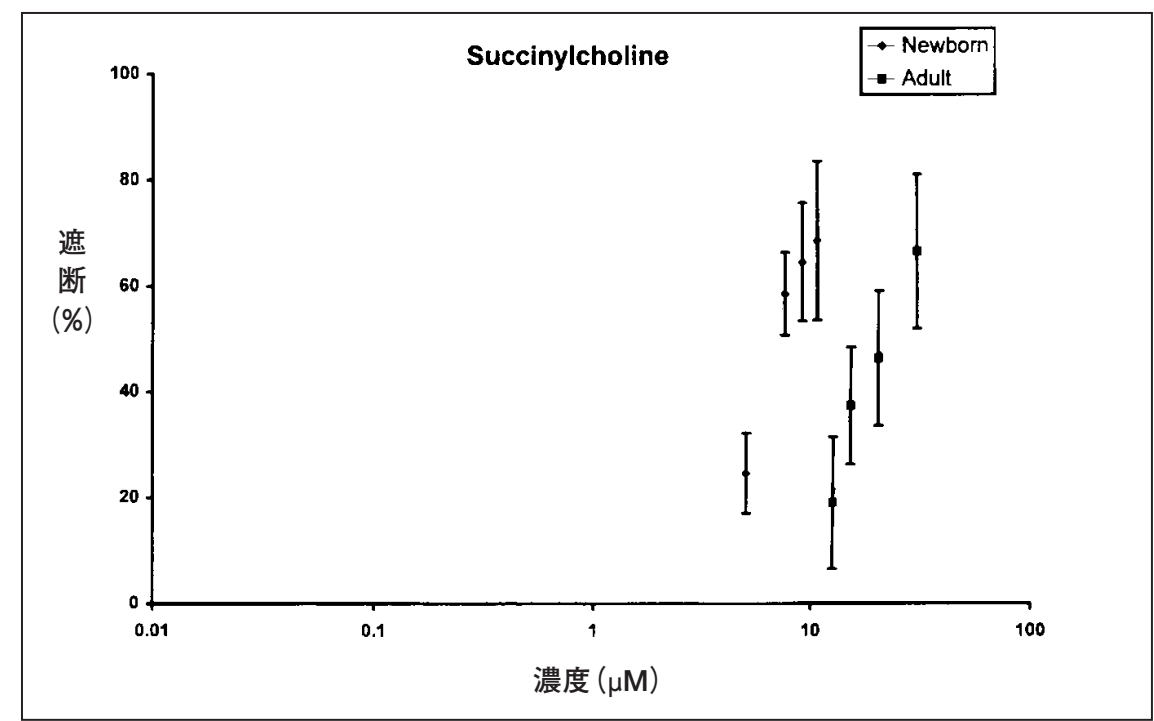

図1 9 12 日ラット(新生児相当)と 27〜 33 日ラット(成人相当)の横隔神経/ 横隔膜標本を用いたスキサメトニウムの効果

四連刺激の T1の\%表示で表わした神経筋遮断効果. それぞれの濃度に対して 「平均土標準偏差」遮断.

〔文献2)より引用・改変〕

経一横隔膜標本を用いて神経筋遮断を起こす濃度を 検討したところ，スキサメトニウム，ベクロニウム， ロクロニウムでは新生児相当のラットの方が低い濃 度で神経筋遮断が起きることがわかった(図1〜図 3)。しかも成人相当のラットでの遮断必要濃度に対 する新生児相当のラットのそれはロクロニウムが一 番小さかった (表1) ${ }^{2)}$ 。このことより，未熟な神経筋 接合部に対する影響はロクロニウムで一番大きいこ とが示唆される。しかし，ベクロニウムおよびロク ロニウムの胎盤通過性は表2のごとくきわめて低く （ただし，ロクロニウムはベクロニウムよりやや高 ( $)^{3)}$ ，母体合併症がない妊婦に対する正期産帝王切 開術において通常挿管に必要な用量を単回用いて正 常新生児に影響を及ぼしたデー夕はみられていな い.すなわち，帝王切開術に際して母体に投与され たこれらの筋弛緩薬が健常正期産児に対する影響は 臨床的にはほとんどないといえる。しかし，未熟児 や，児の神経筋疾患などが疑われるような特殊な病 態例では筋弛緩薬の選択が出生新生児に影響を及ぼ さないともいえない.

\section{II 帝王切開術において筋弛緩薬が必要な状況}

筋弛緩を必要とする全身麻酔の適応は，区域麻酔 が禁忌となるような場合以外はきわめて緊急性の高 い状況であることを認識すべきである。一般的に口 クロニウムでは priming principleによって使用する ロクロニウムの総使用量を減少させながら作用発現 時間の短縮を図る試みがある。しかし primingをし て, $1 \sim 3$ 分待つくらいなら, 帝王切開術に対して は，その間に脊髄くも膜下麻酔を行うことも可能で ある。確かに非妊婦と比較して妊婦では，体重も重 く，皮下脂肪もあり，増大した腹部のために胸膝位 がとりにくいことから脊髄くも膜下腔穿刺が困難で ある。そのような状況では予想外に穿刺に時間がか かることが懸念されるかもしれない.しかし妊婦に おける挿管困難の頻度は高く ${ }^{4)}$ ），肥満妊婦ではさ らにその確率は高くなるため，急速遂婏が必要な状 況では全身麻酔を選択せざるを得ないことが多い一 方で，全身麻酔に伴い大きなリスクを背負う。 


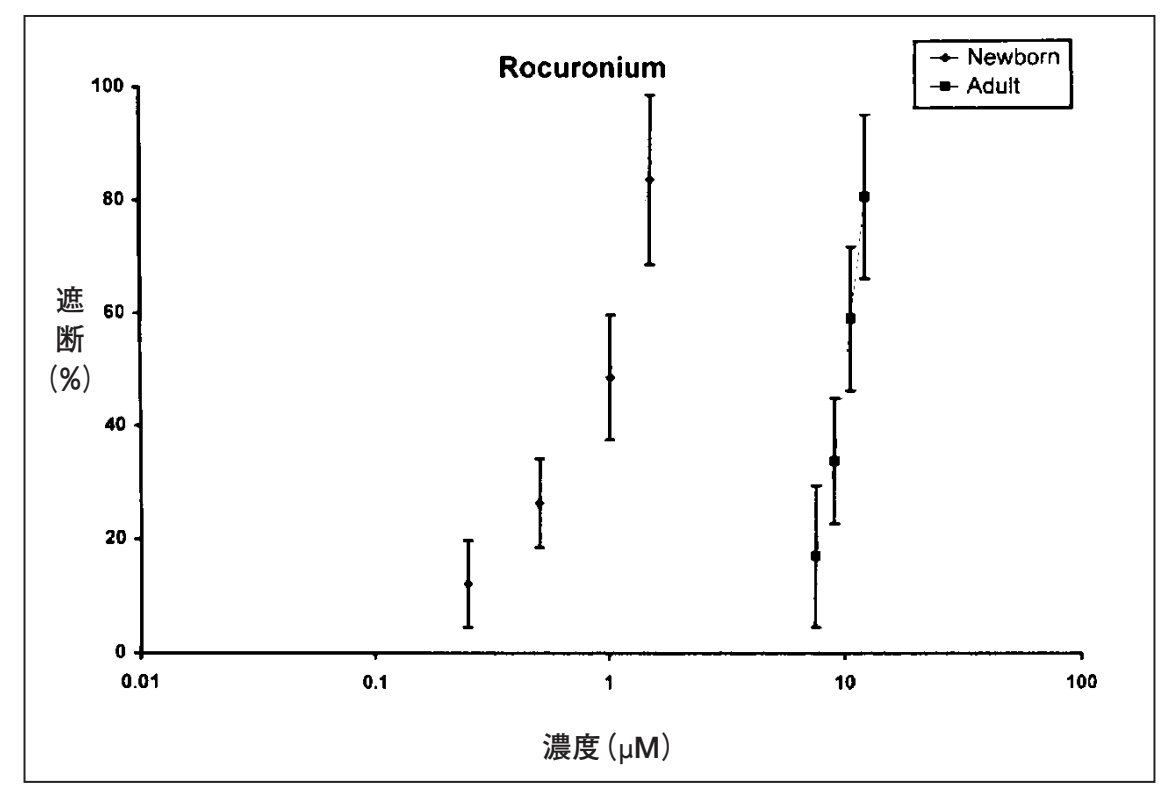

図2 9〜12 日ラット(新生児相当)と 27〜 33 日ラット(成人相当)の横隔神経/ 横隔膜標本を用いたロクロニウムの効果

四連刺激の T1の\%表示で表わした神経筋遮断効果。それぞれの濃度に対して 「平均士標準偏差」遮断.

〔文献2)より引用・改変]

\section{III 挿管困難症例における筋弛緩薬}

緊急時の娩出が必要な場合に，挿管困難症例に対 しては，スキサメトニウムでは自発呼吸の出現を待 ってマスク換気下に急速遂婏ができる。一方，ロク ロニウムではそのようなことはできないため陽圧換 気が必要となるが，それに伴い誤息性肺炎の危険性 が増大する。したがって, 安易にスキサメトニウム の代わりにロクロニウムを用いるべきではないとの 意見がある7),8).

しかし，一方で，妊娠中は偽コリンエステラーゼ 活性が20〜30\%低下していること, 自発呼吸は動脈 酸素飽和度が低下する前に出現するわけではないこ とから ${ }^{9)}$, スキサメトニウムは決して安全に使用で きる筋弛緩薬ではない. 筋弛緩効果が消失する際に 喉頭痤攣や嘔吐を起こすと, 浮腫状になった妊婦の 気道を介する換気が困難になる可能性がある。スキ サメトニウムで循環動態や筋弛緩状態が不安定な状 態に陥るよりも，むしろ落ち着いて挿管に対処で
きる非脱分極性筋弛緩薬の方が望ましいとの意見も ある ${ }^{10)}$.

近年はファイバースコープのみならず，ラリンジ アルマスク，マッコイ喉頭鏡，ブラード喉頭鏡，スタ イレットスコープ, トラキライト，エアトラック，エ アウェイスコープ，グライドスコープ，ガムエラス ティックブジー，コンビチューブなど数えきれない ほどの抻管困難に対する気道確保器具が開発されて きたため，それらを活用すれば抻管困難に安全に対 応可能であるともいえる。もちろんこれらは緊急で 児婏出を図ることと同時進行になることもありうる.

\section{IV ロクロニウムの用量と良好な挿管環境}

一般的にはロクロニウムの用量を多くするとスキ サメトニウムと同等の速さの作用発現を得ることが 可能である. Abu-Halawehらは帝王切開術の際に, チオペンタール $5 \mathrm{mg} / \mathrm{kg}$ にロクニウム $1 \mathrm{mg} / \mathrm{kg}$ を 用いると，スキサメトニウム $1 \mathrm{mg} / \mathrm{kg}$ と同様 $96 \%$ 前 後の良好な挿管状態を得ることができたと報告し 


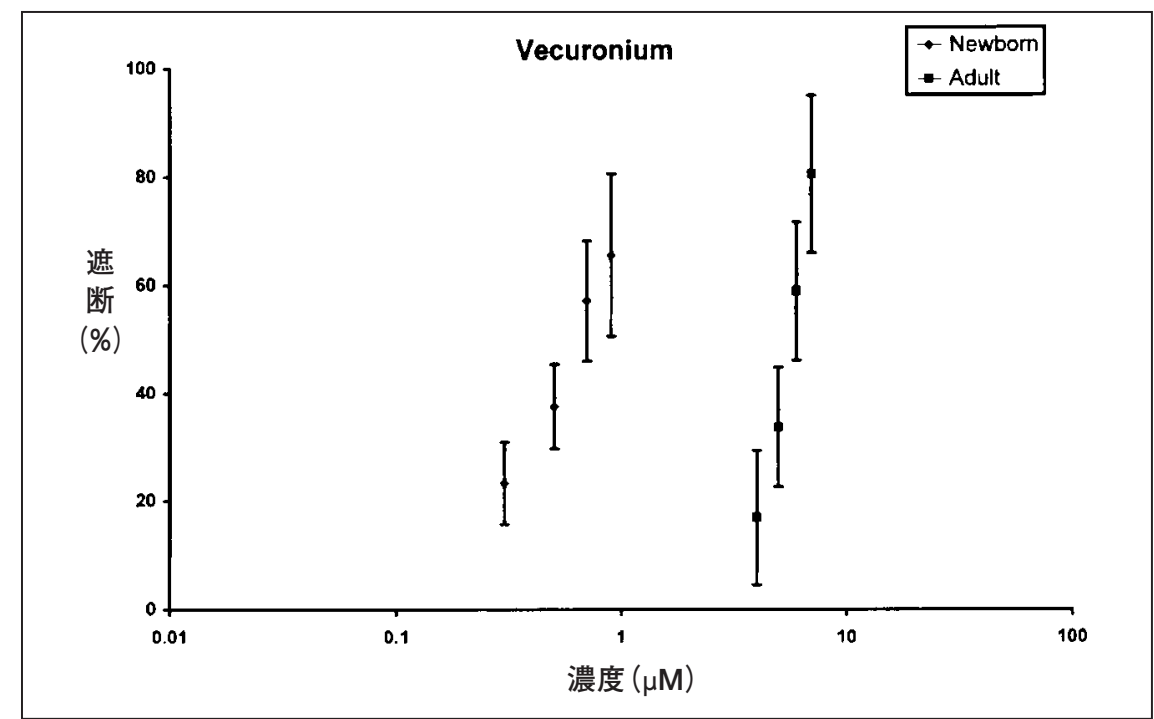

図3 9 12 日ラット(新生児相当)と 27〜 33 日ラット(成人相当)の横隔神経/ 横隔膜標本を用いたベクロニウムの効果

四連刺激の T1の\%表示で表わした神経筋遮断効果. それぞれの濃度に対して 「平均土標準偏差」遮断.

〔文献2)より引用・改変〕

た ${ }^{11)}$.しかしこの場合には，帝王切開の手術時間を 超えて作用が遷延する可能性が高いために不必要な 全身麻酔が必要となる。それではロクロニウムの用 量を減らし，良好な挿管状態を得る方法はあるので あろうか。

Abouleish らは $6 \mathrm{mg} / \mathrm{kg}$ のオペンタールと $0.6 \mathrm{mg} / \mathrm{kg}$ のロクロニウムで帝王切開術の麻酔導入 を行うと $90 \%$ 以上で良好な挿管状態が確保されたと 報告した ${ }^{1)}$ 。しかし，このようにチオペンタールの 量を通常より多く用いることで良好な挿管状態を得 ることに対しては, 児の抑制を起こす可能性が増大 することから批判的な意見が多い ${ }^{12}$.

帝王切開術に対する麻酔導入薬として $4 \mathrm{mg} / \mathrm{kg}$ の チオペンタールの代わりに $1.5 \mathrm{mg} / \mathrm{kg}$ のケタミンを 用い, これら両群に筋弛緩薬として $0.6 \mathrm{mg} / \mathrm{kg}$ の口 クロニウムを加えて挿管したところ, チオペンター ル群と比較してケタミン群では挿管時の下顎や声帯 の弛緩，横隔膜の動きがはるかに少なかったと報告 されている ${ }^{13)}$.しかもこの研究では, 児娩出までに チオペンタール群では術中覚醒を防ぐために亜酸化
窒素や吸入麻酔薬が必要だが，ケタミンは単剤でそ れを予防できたとの結果も得た。しかしケタミンに は幻覚発生の危険性や，妊娠高血圧症候群，妊娠高 血圧腎症などを合併している場合には高血圧危機の 危険性を負う。

\section{V ロクロニウムの妊婦における作用時間}

ベクロニウムと同様に，ロクロニウムでも産裖期 には筋弛緩薬の作用時間が延長することが報告され ている ${ }^{14), 15)}$ 。これには妊娠中の体重増加により総投 与量が非妊時より多くなることも影響していると推 測されている。しかし，一方で帝王切開術に際して ベクロニウムを使用した場合，一般成人男女よりも クリアランスは高く，半減期が短いことが報告され ている ${ }^{16), 17)}$ 。したがって産裖期にみられる筋弛緩薬 の作用遷延が帝王切開術においても同様にみられる かどうかは議論の余地がありそうである。これらの 作用時間に関する結果の差の原因は明らかではない が，帝王切開術においては胎児および胎盤が娩出さ れること（胎盤を介して移行する薬物は少ないなが 


\begin{tabular}{|c|c|c|c|}
\hline \multicolumn{4}{|c|}{$\mathrm{EC}_{50}(\mu \mathrm{M})$} \\
\hline \multirow[b]{2}{*}{ Relaxant } & \multicolumn{2}{|c|}{$($ Mean \pm SD $)$} & \multirow{2}{*}{$\begin{array}{c}\text { Ratio } \\
(\text { Mean } \pm \text { SEM })\end{array}$} \\
\hline & Adult & Newborn & \\
\hline \multicolumn{4}{|l|}{ Depolarizing } \\
\hline 1. Succinylcholine & $21.3 \pm 1.3$ & $7.3 \pm 2.3$ & $2.9 \pm 0.4^{23,4,5,5,6}$ \\
\hline \multicolumn{4}{|l|}{ Nondepolarizing } \\
\hline 2. $d$-Tubocurarine & $1.68 \pm 0.52$ & $0.23 \pm 0.08$ & $7.3 \pm 1.5^{1}$ \\
\hline 3. Atracurium & $12.3 \pm 2.5$ & $1.90 \pm 0.26$ & $6.5 \pm 0.7^{1,6}$ \\
\hline 4. cis-Atracurium & $2.73 \pm 0.23$ & $0.47 \pm 0.09$ & $5.8 \pm 0.5^{1,6}$ \\
\hline 5. Vecuronium & $5.47 \pm 0.45$ & $0.59 \pm 0.22$ & $9.3 \pm 1.6^{1}$ \\
\hline 6. Rocuronium & $9.7 \pm 0.7$ & $0.78 \pm 0.20$ & $12.5 \pm 1.4^{1,3,4}$ \\
\hline
\end{tabular}

各群 5 匹. 右肩の番号は相当番号の筋弛緩薬との有意差 $(\mathrm{p}<0.05$, Tukey 分析).

〔文献2)上り引用・改変〕

表2 ベクロニウムおよびロクロニウムの胎盤通過性

\begin{tabular}{lcc}
\hline & ベクロニウム & ロクロニウム \\
\hline 臍帯静脈 /母体静脈比 & 0.11 & 0.16 \\
臍帯動脈 /臍帯静脈比 & 0.45 & 0.35 \\
臍帯動脈 $/$ 母体静脈比 & 0.06 & 0.11 \\
\hline & & 〔文献3)より引用・改変〕
\end{tabular}

らもある), かつ $500 \mathrm{~m} l$ 以上の出血があるため輸液 により循環血液量が希釈されること, 妊娠中に増加 したプロゲステロンが肝代謝を促進するといつた要 因が短い作用時間と関係しているものと推測されて いる.

\section{Vロクロニウムはスキサメトニウムに とって代わるか?}

スキサメトニウムは万能の筋弛緩薬ではない。投 与 60 秒後でも $100 \%$ 良好な挿管状態が達成されるわ けではない. 悪性高熱症を疑わせる咬筋硬直, 徐脈, 高カリウム血症, 筋肉痛の危険性がある。女性では 男性より筋肉痛の発生は少ないとされているが， ス キサメトニウムを使用した帝王切開術後の妊婦の $7.5 \%$ では背中や頸に筋肉痛を発症したとの報告もあ る ${ }^{18)}$ 。また多くの神経筋疾患ではスキサメトニウム
は禁忌である。

一方, ベクロニウムでは緊急挿管時の筋弛緩薬と して作用発現の速さの面からスキサメトニウムには 到底かなわないが19)，ロクロニウムの場合は用量に よってはスキサメトニウムと同等の速い作用発現は 可能である。咬筋硬直, 徐脈, 高カリウム血症, 筋 肉痛の危険性もなく, ヒスタミン遊離やアナフィラ キシーの頻度も少ない.

したがって今後スキサメトニウムよりも使用され る症例は増加するものと予想される。しかしロクロ ニウムの用量によっては手術終了後の筋弛緩の残存 が問題となる。児への安全性も決して完全に確立さ れたわけではない.

選択的拮抗薬スガマデクスが使用可能となり，ス ガマデクスおよびロクロニウムとの複合体の妊婦や 胎児に対する安全性が確立されるまでは，このよう 
にスキサメトニウムとロクロニウムの使用に関して の優劣はいまだ完全にはつけ難い.

\section{結＼cjkstart語}

副作用の面からはロクロニウムが望ましいが，帝 王切開における使用においては作用発現時間, 持続 時間の面で完全ではない，児への安全性も決して完 全に確立されたわけではない。したがって全身麻酔 の適応と筋弛緩薬の選択には依然慎重な考慮が必要 であり，一般手術より遭遇頻度の高い挿管困難に対 する対策は万全に整えておくべきである。

\section{参考文献}

1) Abouleish E, Abboud T, Lechevalier T, et al. : Rocuronium (Org 9426) for caesarean section. Br J Anaesth 73 : 336-341, 1994

2) Fortier LP, Robitaille R, Donati F : Increased sensitivity to depolarization and nondepolarizing neuromuscular blocking agents in young rat hemidiaphragms. Anesthesiology 95 : 478-484, 2001

3) Wierda JMKH, Proost JH : The pharmacokinetics and the pharmacokinetic-dynamic relationship of rocuronium bromide. Anaesth Pharmacol Rev 3 : 192-201, 1995

4) Lyons G : Failed intubation. Six years' experience in a teaching maternity unit. Anaesthesia 40 : 759-762, 1985

5) Barnardo PD, Jenkins JG : Failed tracheal intubation in obstetrics : a 6-year review in a UK region. Anaesthesia 55 : 690-694, 2000

6) Rahman K, Jenkins JG : Failed tracheal intubation in obstetrics : no more frequent but still managed badly. Anaesthesia 60 : 168-171, 2005

7) Priestley GS, Swales HA, Gaylard DG : Rocuronium for caesarean section. Br J Anaesth $74:$ 348, 1995

8) McSwiney M, Edwards C, Wilkins A : Rocuronium for caesarean section. Br J Anaesth 74 : 348, 1995

9) Benumof JL, Dagg R, Benumof R : Critical hemoglobin desaturation will occur before return to an unparalyzed state following $1 \mathrm{mg} / \mathrm{kg}$ intravenous succinylcholine. Anesthesiology 87 : 979-982, 1997

10) Levy DM : Non-depolarising neuromuscular blockers can be used routinely instead of suxamethonium at induction of general anaesthesia for caesarean section. Int J Obstet Anesth 8 : 266-272, 1999

11) Abu-Halaweh SA, Massad IM, Abu-Ali HM, et al. : Rapid sequence induction and intubation with 1 $\mathrm{mg} / \mathrm{kg}$ rocuronium bromide in cesarean section, comparison with suxamethonium. Saudi Med J 28 : 13931396, 2007

12) Kwan WF, Chen BJ, Liao KT : Rocuronium for caesarean section. Br J Anaesth 74 : 347, 1995

13) Baraka AS, Sayyid SS, Assaf BA : Thiopental-rocuronium versus ketamine-rocuronium for rapidsequence intubation in parturients undergoing cesarean section. Anesth Analg 84 : 1104-1107, 1997

14) Camp CE, Tessem J, Adenwala J, et al. : Vecuronium and prolonged neuromuscular blockade in postpartum patients. Anesthesiology 67 : 1006-1008, 1987

15) Pühringer FK, Sparr HJ, Mitterschiffthaler G, et al. : Extended duration of action of rocuronium in postpartum patients. Anesth Analg 84 : 352-354, 1997

16) Cronnelly R, Fisher DM, Miller RD, et al. : Pharmacokinetics and pharmacodynamics of vecuronium (ORG NC45) and pancuronium in anesthetized humans. Anesthesiology 58 : 405-408, 1983

17) Dailey PA, Fisher DM, Shnider SM, et al. : Pharmacokinetics, placental transfer, and neonatal effects of vecuronium and pancuronium administered during cesarean section. Anesthesiology 60 : 569-574, 1984

18) Thind GS, Bryson TH : Single dose suxamethonium and muscle pain in pregnancy. Br J Anaesth 55 : 743745,1983

19) Hawkins JL, Johnson TD, Kubicek MA, et al. : Vecuronium for rapid-sequence intubation for cesarean section. Anesth Analg 71 : 185-190, 1990 


\title{
Controversial Issues Regarding Rocuronium during the Induction of General Anesthesia for Cesarean Section
}

\author{
Toshiyuki OKUTOMI \\ Department of Anesthesiology, Kitasato University School of Medicine
}

\begin{abstract}
When rocuronium is used during cesarean section, one should be aware of the effects of the agent on the maternal-fetal unit. For the sake of its safe and effective usage, the effects of physiological change with pregnancy and pathophysiology on the indication of general anesthesia should be well acquainted. At this point, there is little difference between rocuronium and suxamethonium. Although rocuronium has less disadvantageous effects than suxamethonium, it is not always superior in terms of onset and duration for cesarean section. Whenever either muscle relaxant is utilized in the induction of general anesthesia for cesarean section, one should be prepared in case of difficult airway.

Key Words : Physiological change, Pregnancy, Placental transfer, Difficult airway
\end{abstract}

The Journal of Japan Society for Clinical Anesthesia Vol.28 No.4, 2008 